\title{
UPAYA PENINGKATAN PARTISIPASI PUS DALAM KELUARGA BERENCANA DI DUSUN GUNUNG KAWUNG DESA CIKUNIR KECAMATAN SINGAPARNA KABUPATEN TASIKMALAYA TAHUN 2019
}

\author{
OLEH: \\ Annisa Rahmidini, SST,M.Keb \\ Teni Supriyani,S.Si, M.KM, Adam Akbar Maulana
}

\section{STIKes Respati}

Email : annisarahmidini@gmail.com

\section{A.DASAR PEMIKIRAN}

\begin{abstract}
Indonesia merupakan sebuah negara berkembang dengan jumlah penduduk sebanyak 252.124.458 jiwa dengan luas wilayah 1.913.378,68 km2 dan kepadatan penduduk sebesar 131,76 jiwa/km2 (Depkes RI, 2014). Masalah yang terdapat di Indonesia adalah laju pertumbuhan penduduk yang 2 relatif masih tinggi. Perkiraan penduduk pertengahan (2013) sebesar 248,8 juta jiwa dengan laju pertumbuhan penduduk sebesar $1,48 \%$. Laju pertumbuhan ditentukan oleh kelahiran dan kematian dengan adanya perbaikan pelayanan kesehatan menyebabkan tingkat kematian rendah, sedangkan tingkat kelahiran tetap tinggi hal ini penyebab utama ledakan penduduk.
\end{abstract}

Cakupan peserta $\mathrm{KB}$ baru dan KB aktif di Indonesia pada tahun 2014 dengan jumlah Pasangan Usia Subur (PUS) sebanyak 47.019.002. Peserta KB baru sebesar 7.761.961 (16,15\%) meliputi suntik sebanyak 3.855.254 $(49,67 \%)$, pil KB sebanyak 1.951.252 $(25,14 \%)$, kondom sebanyak 441.141 $(5,68 \%)$, implan sebanyak 826.627 (10,65\%), IUD (Intra Uterine Device) sebanyak 555.241 (7,15\%), Metode
Operasi Wanita (MOW) sebanyak 116.384 (1,5\%), Metode Operasi Pria (MOP) sebanyak $16.062 \quad(0,2 \%)$. Sedangkan peserta KB aktif sebanyak 35.202.908 meliputi IUD sebanyak 3.896.081 (11,07\%), MOW sebanyak 1.238.749 (3,52\%), MOP sebanyak $241.642(0,69 \%)$, implant sebanyak $3.680 .816(10,46 \%)$, kondom sebanyak $1.110 .341(3,15 \%)$, suntikan sebanyak $16.734 .917(47,54 \%)$, dan pil KB sebanyak 8.300.362 (29,58\%) (Depkes RI, 2014).

Dari hasil penelitian yang diketahui banyak alasan dikemukkan oleh wanita yang tidak menggunakan kontrasepsi, antara lain karena menginginkan anak. Alasan yang cukup menonjol adalah karena efek samping dan masalah kesehatan, dengan pasangan yang menolak (10\%), alasan karena agama $(0,5 \%)$ dan alsan yang berkaitan dengan kondisi sosial ekonomi yaitu biaya yang mahal $(0,8 \%)$ (BKKBN,2010). Faktor ketidak berhasilan gerakan keluarga berencana dipengaruhi oleh faktor, umur pasangan usia subur (15- 49 tahun), pendidikan (SD, SMP, SMA, Perguruan Tinggi), pekerjaan (pertanian dan non pertanian), budaya 
(faktor keturunan, banyak anak banyak rejeki, anak sebagai faktor ekonomi, kualitas pelayanan akseptor KB (pilihan metode kontrasepsi, kualitas pemberian informasi, kemampuan teknis petugas, hubungan interpersonal, mekanisme pelayanan ketetapan konstelasi pelayanan akseptor $\mathrm{KB}$, strategi penerapan pelaksanaan gerakan keluarga berencana). (BKKBN, 2016).

Upaya telah dilakukan pemerintah untuk menekan angka pertumbuhan penduduk dengan pembentukan Kampung KB, Pelayanan KB gratis untuk keluarga kurang mampu, pembinaan Generasi Berencana (GenRE), pembinaan kelompok kegiatan BKB, BKR, BKL dan UPPKS, pembinaan PIK-R serta pembinaan dan pelatihan - pelatihan tenaga penggerak desa.

Dalam kurun satu tahun jumlah pertambahan penduduk di kabupaten tasikmalaya yang mempunyai 39 kecamtan mencapai 30 ribu jiwa tingkat pertumbuhan penduduk di kabupaten tasikmlaya cukup tinggi jika di persentasekan jumlah pertumbuhan penduduk $1,4 \%$ dari total populasi kabupaten tasikmalaya bahkan persentase nya hampir sama dengan tingkat pertumbuhan penduduk secara nasional yang di angka $14 \%$ Kepala dinas BKKBN Kabupaten Tasikmalaya jumlah penduduk sebanyak itu sudah sepadan dengan populasi sebuah kecamatan Untuk mengendalikan jumlah penduduk pihaknya terus menggiatkan sosialisasi program keluarga berencana kepada warga Kepala dinas BKKBN menyebut masih ada sekitar 47 Ribu pasangan usia subur di Kabupaten Tasikmlaya yang belum ber status akseptor KB . Jumlah tersebut mencapai $13 \%$ dari total populasi pasangan usia subur Upaya nya terus mensosialisasi secara door to door ke masyarakat di desa desa agar semua kalangan bisa tersentuh ( BKKBN Kabupaten Tasikmlaya )

Berdasarkan data Praktek Belajar Lapangan I (PBL I) yang dilakukan di Dusun Gunung Kawung Desa Cikunir Kabupaten Tasikmalaya Tahun 2018, di dapatkan hasil frekuensi kontrasepsi Dari 61 Orang (60.6\%) Pasangan Usia Subur terdapat 38 Orang (39.4\%) wanita subur tidak Ber KB. Berdasarkan wawancara dengan kader, jenis $\mathrm{KB}$ yang di gunakan di dusun Gunung kawung mayoritas menggunakan KB suntik sebanyak 46 Orang (75.4\%), berdasarkan alasan menggunakan KB di dusun Gunung kawung sebanyak 28 orang (45.9\%) menjarangkan kehamilan sebanyak 18 Orang $(29.5 \%)$ menunda kehamilan 15 orang (24.6\%) Ketidak sesuaian jenis KB dengan alasan penggunaan $\mathrm{KB}$ terdapat 28 orang tujuan menjarangkan kehamilan menggunakan PIL kb 4 Orang (14.3\%) menggunakan kondom 1 Orang (3.6\%) yang menggunakan IUD 2 orang (11.1).

\section{B.TUJUAN}

Untuk Meningkatkan partisipasi PUS dalam ber KB melalui peningkatan Pengetahuan tentang Kesesuaian Alat Kontrasepsi Melalui Penyuluhan di Dusun Gunung Kawung Desa Cikunir Kecamatan Singaparna Kabupaten Tasikmalaya tahun 2019 


\section{SASARAN}

Sasaran kegiatan ini adalah 52 orang pasangan usia subur yang terdistribusi di Kampung Sunia Babakan Dawuan, serta Margamulya

\section{WAKTU DAN TEMPAT}

Kegiatan ini dilaksanakan pada bulan Maret 2019 di madrasah dan posyandu.

\section{F. HASIL KEGIATAN}

Pelaksanaan kegiatan untuk meningkatkan partisipasi masyarakat dalam ber KB (Keluarga Berencana) dilakukan dalam 3 hari bulan Maret tahun 2019 di laksanakan di tiga tempat yaitu di rumah Warga dan Posyandu Babakan Dawuan Posyandu Margamulya dengan materi yang diberikan mengenai Alat Kontrasepsi dengan tujuan Program KB dengan sub topik : Definisi KB, Jenis KB, Tujuan Ber KB, Metode KB dan Alat Kontrasepsi.

Dalam kegiatan ini didapatkan beberapa hal yang kurang dipahami oleh sasaran diantaranya:

1. Keuntungan pengguna alat kontrasepsi implant

Keuntungan pengguna alat kontrasepsi implant adalah :
a. Daya guna tinggi
b. Perlindungan jangka panjang
c. Pengembalian tingkat kesuburan yang cepat setelah pencabutan
d. Tidak memerlukan pemeriksaan dalam
e. Tidak mengganggu dari kegiatan senggama
f. Tidak mengganggu ASI g)Klien hanya kembali jika ada keluhan
g. Dapat dicabut sesuai dengan kebutuhan

h. Mengurangi nyeri haid j)Mengurangi jumlah darah haid

i. Mengurangi dan memperbaiki anemia

j. Melindungi terjadinya kanker endometrium

k. Melindungi angka kejadian kelainan jinak payudara

1. Melindungi diri dari beberapa penyebab penyakit radang panggul

m. Menurunkan kejadian
endometriosis

2. Efek samping pengguna alat kontrasepsi KB suntik

Faktor dampak dalam penggunaan alat kontrasepsi hormonal Terdapat sebanyak $87,5 \%$ WUS yang sebelumnya menggunakan alat kontrasepsi hormonal seperti KB Suntik akan tetapi mengalami dampak yang menjadikan responden tidak menggunakan alat kontrasepsi kembali seperti pendarahan, masalah siklus menstruasi yang tidak teratur, kenaikkan berat badan.

Menurut Kemenkes RI (2013) penggunaan $\mathrm{KB}$ suntik 1 bulan akan menimbulkan dampak / efek samping yang dapat terjadi seperti gangguan haid, depresi, keputihan, jerawat, perubahan berat badan, pemakaian jangka panjang terjadi penurunan libido, dan desintas tulang. Sedangkan KB suntik 3 bulan akan menimbulkan dampak / efek samping seperti siklus menstruasi memendek atau memanjang, pendarahan yang banyak atau sedikit, spotting, tidak haid sama sekali, tidak dapat di hentikan sewaktu - waktu, permasalahan berat badan, terlambatnya kembali kesuburan setelah penghentian pemakaian, 
terjadi perubahan pada lipid serum pada penggunaan jangka panjang, pada penggunaan jangka panjang dapat menurunkan kepadatan tulang (desintas), pada penggunaan jangka panjang dapat menimbulkan kekeringan pada vagina, menurunkan libido, gangguan emosi, sakit kepala, nervositas dan jerawat.

3. Metode kontrasepsi sederhana Metode kontrasepsi sederhana terdiri dari 2 yaitu metode kontrasepsi sederhana tanpa alat dan metode kontrasepsi dengan alat. Metode kontrasepsi tanpa alat antara lain: Metode Amenorhoe Laktasi (MAL), Couitus Interuptus, Metode Kalender, Metode Lendir Serviks, Metode Suhu Basal Badan, dan Simptotermal yaitu perpaduan antara suhu basal dan

\section{G. DOKUMENTASI}
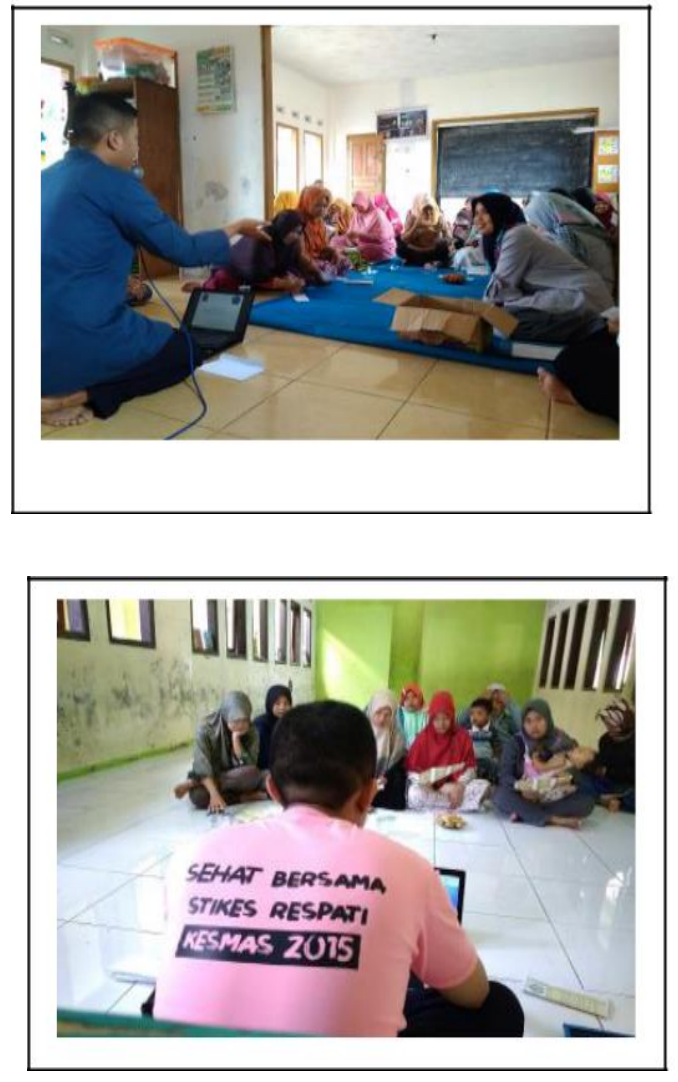

lendir servik. Sedangkan metode kontrasepsi sederhana dengan alat yaitu kondom, diafragma, cup serviks dan spermisida
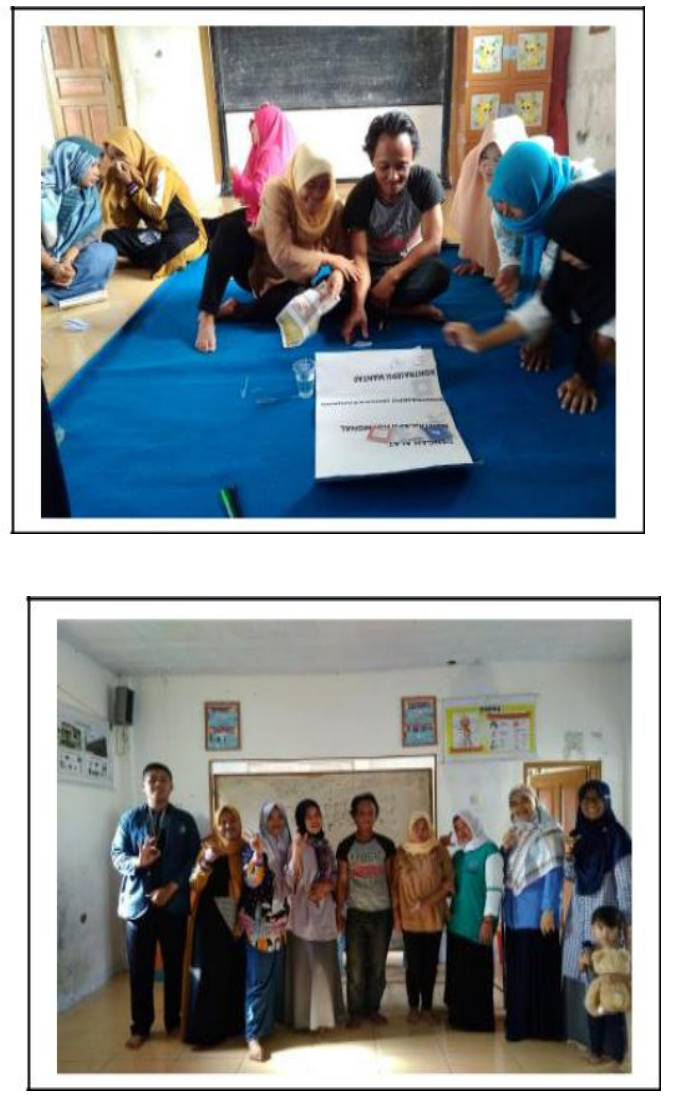